\title{
Kontribusi Rasio Aktivitas dan Ukuran Perusahaan pada Rentabilitas PT. Telekomunikasi Indonesia (Persero), Tbk
}

\author{
Muh. Ilham Harris ${ }^{1}$, Herman Sjahruddin ${ }^{2}$, Orfyanni S. Themba ${ }^{3}$
}

${ }^{1-3)}$ Sekolah Tinggi Ilmu Ekonomi Makassar Bongaya, email : muhammadilham.mih2@gmail.com

\begin{tabular}{cc} 
ARTICLES & ABSTRACT \\
INFORMATION & \\
\hline
\end{tabular}

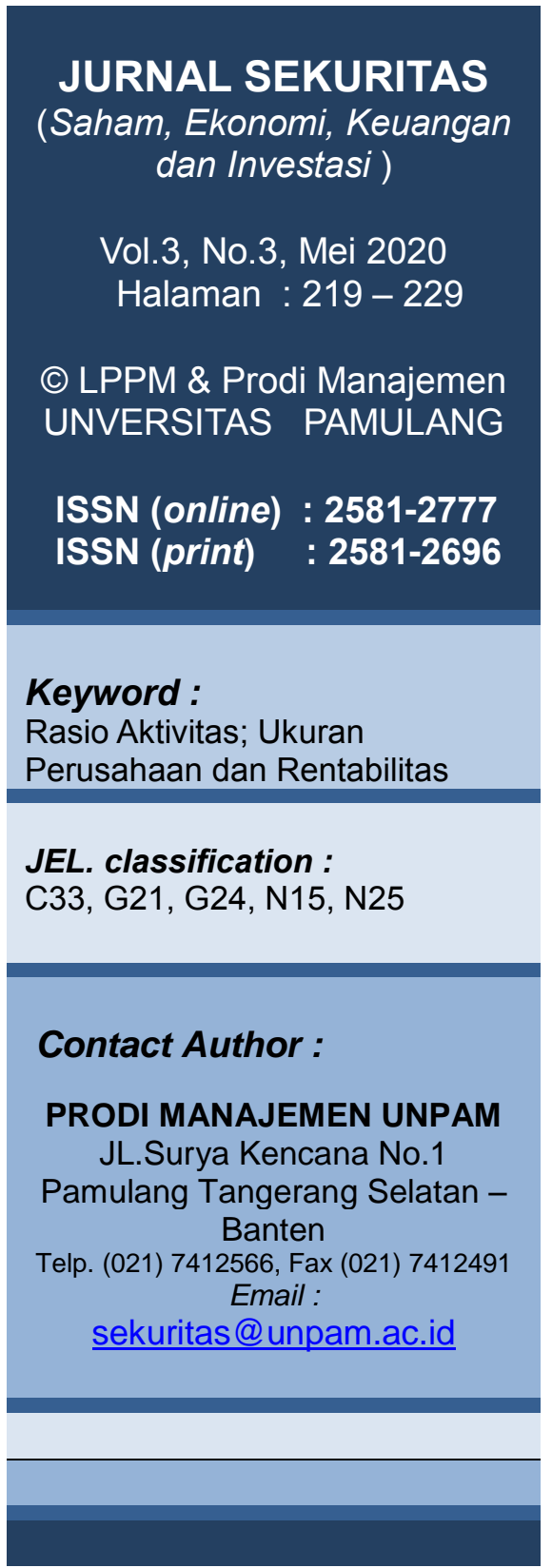

Kami berupaya menguji kembali kontribusi rasio aktivitas dan ukuran perusahaan pada rentabilitas PT. Telekomunikasi Indonesia (Persero) Tbk sebagai tujuan dilakukannya studi ini. Populasi penelitian adalah Laporan keuangan triwulan Tahun 2009 - 2018 dengan memanfaatkan purposive sampling dalam pengambilan sampel sehingga diperoleh $4 \times 10=40$ unit data sebagai sampel. Analisis data menggunakan regresi linear berganda melalui pemanfaatan SPSS Ver. 25. Temuan studi ini memberikan bukti bahwa rasio aktivitas (TATO) dan ukuran perusahaan (LnTA) memberikan kontribusi positif signifikan pada rentabilitas (ROA) perusahaan.

We are trying to reexamine the contribution of activity ratio and firm size to the profitability of PT. Telekomunikasi Indonesia (Persero) Tbk as the purpose of this research. The study population is the 2009-2018 financial statements by utilizing purposive sampling in sampling to obtain $4 \times 10=40$ data units as samples. Data analysis using multiple linear regression through the use of SPSS Ver. 25. The findings of this study provide evidence that the activity ratio (TATO) and firm size (LnTA) make a positive significant contribution to rentability (ROA) 


\section{A. PENDAHULUAN}

Perusahaan telekomunikasi Indonesia atau yang biasa disebut dengan PT. Telekomunikasi Indonesia (Persero), Tbk merupakan salah satu perusahaan milik pemerintah yang bergerak pada bidang penyelenggaraan jasa dan jaringan telekomunikasi, pada Bursa Efek Indonesia perusahaan tercatat pada Sektor Perusahaan jasa sektor infrastruktur utilitas dan transportasi Sub Sektor telekomunikasi. Perusahaan mengalami tekanan yang cukup berat pada tahun 2019. Persaingan bisnis yang ketat hingga regulasi yang tidak mendukung menjadi sejumlah faktor yang menggerus nilai bisnis komunikasi. Perang tarif menjadi salah satu penyebab kurang sehatnya industri telekomunikasi, khususnya seluler. Persaingan antar operator di Indonesia terbilang paling keras di dunia. Asosiasi Telekomunikasi Seluruh Indonesia (ATSI) menyebut, pendapatan industri telekomunikasi pada 2018 mencapai Rp.148 Triliun, turun 6,4 persen dibandingkan Tahun 2017 yang mencapai Rp.158 Triliun. (https://beritagar.id/, diunduh 23 Januari 2020).

Fakta empiris menunjukkan bahwa hingga kuartal III tahun 2018, PT. Telekomunikasi Indonesia (Persero) Tbk. Melaporkan penurunan laba bersih sebesar Rp. 14.426 triliun, turun 20,59 persen dibandingkan periode yang sama (year-on-year / year-on-year) di tahun 2017 sebesar Rp17.922 triliun. Penurunan tersebut dapat juga ditunjukkan pada nilai Return on Assets sebagai proksi dalam mengukur rentabilitas perusahaan, seperti yang diperlihatkan tabel dibawah ini:

Tabel 1. Return on assets (ROA) PT. Telekomunikasi Indonesia (Persero) Tbk Periode 2014-2018

\begin{tabular}{|c|c|c|c|c|}
\hline \multirow[b]{2}{*}{ Tahun } & \multicolumn{3}{|c|}{ Rentabilitas } & \multirow[b]{2}{*}{$\begin{array}{l}\text { Perubahan } \\
(\%)\end{array}$} \\
\hline & $\begin{array}{c}\text { Laba Bersih } \\
\text { (Dalam Bentuk } \\
\text { Rupiah) } \\
\end{array}$ & $\begin{array}{c}\text { Total Aset } \\
\text { (Dalam Bentuk Rupiah) }\end{array}$ & $\begin{array}{l}\mathrm{ROA} \\
(\%)\end{array}$ & \\
\hline 2014 & $13,344,000,000,000.00$ & $134,950,500,000,000.00$ & 9.89 & - \\
\hline 2015 & $14,285,250,000,000.00$ & $156,322,250,000,000.00$ & 9.14 & -0.75 \\
\hline 2016 & $18,224,250,000,000.00$ & $176,369,000,000,000.00$ & 10.33 & 1.19 \\
\hline 2017 & $21,396,250,000,000.00$ & $188,606,250,000,000.00$ & 11.34 & 1.01 \\
\hline 2018 & $17,112,750,000,000.00$ & $204,912,250,000,000.00$ & 8.35 & -2.99 \\
\hline Rata-Rata & $16,872,500,000,000.00$ & $172,232,050,000,000.00$ & 9.81 & -0.38 \\
\hline
\end{tabular}

Sumber: PT. Telekomunikasi Indonesia ,Tbk (data diolah, 5 januari 2020)

Tabel 1 menunjukkan bahwa return on asset (ROA) perusahaan cenderung mengalami penurunan sejak tahun 2014-2018, penurunan tersebut menjadi alasan dilakukannya penelitian ini pada PT. Telekomunikasi Indonesia (Persero) Tbk. Terdapat faktor yang dominan dalam memengaruhi Return On Assets, yaitu rasio aktivitas dan ukuran perusahaan, hasil studi terdahulu memberikan bukti bahwa kedua rasio tersebut berpengaruh positif dalam meningkatkan ROA (Pratama \& Wiksuana, 2016; Handayani \& Hadi, 2019; Hasibuan, 2019).

Temuan peneliti terkait dengan teori sinyal, yaitu, perusahaan memberikan informasi kepada investor melalui laporan keuangan untuk menunjukkan tingkat kinerja keuangan perusahaan, yang dapat dicerminkan oleh aktivitas perusahaan (rasio aktivitas), ukuran perusahaan, dan profitabilitas perusahaan. Di mata investor dan kreditor, kemampuan perusahaan untuk mengelola kegiatannya dengan baik akan mendapatkan reputasi yang baik, membuatnya lebih mudah untuk mendapatkan kredit, dan laba yang dihasilkan akan meningkat, dan semakin besar tingkat aktivitas (semakin tinggi) atau lebih cepat, Keuntungan yang dihasilkan akan meningkat. Skala tinggi perusahaan telah sangat meningkatkan profitabilitas perusahaan. Alasannya adalah bahwa ukuran perusahaan 
menunjukkan kekayaan perusahaan, semakin besar kekayaan perusahaan, semakin tinggi kemampuan perusahaan untuk mendapatkan keuntungan. (Hasibuan, 2019).

Pemilihan variabel rasio Aktivitas karena rasio aktivitas menilai kemampuan perusahaan dalam pemanfaatan aset perusahaan. (Destika, 2016). Total Assets Turn Over (TATO), sebagai pengukur dari pemanfaatan aset, memiliki fungsi penting dalam menilai perputaran aktiva (Kasmir, 2017:185).

Penggunaan teori sinyal yang telah dikemukakan sebelumnya didukung oleh peneliti lain (Ambarwati dkk, 2015; Handayani \& Hadi, 2019; Hasibuan, 2019) Fakta telah membuktikan bahwa rasio TATO dapat secara signifikan meningkatkan ROA. Studi lain menunjukkan hasil yang berbeda sehingga TATO tidak dapat memberikan kontribusi yang berarti untuk meningkatkan ROA (Setiawan, 2015; Destika, 2016).

Selain rasio aktivitas, ada faktor lain yang mempengaruhi profitabilitas, yaitu ukuran perusahaan. Pemilihan variabel ukuran perusahaan didasarkan pada fungsinya, fungsi ini dapat menunjukkan skala besar ataupun kecilnya suatu perusahaan, yang dapat ditunjukan dalam total aset, penjualan, dan kapitalisasi pasar. Perusahaan besar memiliki dampak pada rentabilitas karena mereka dianggap lebih berisiko (Sukmayanti \& Triaryati Nyoman, 2019).

Beberapa peneliti sebelumnya menggunakan logaritma natural (Ln) dari total aset sebagai proksi untuk menganalisis ukuran perusahaan untuk meminimalkan ambiguitas dalam data total aset, seperti dalam penelitian ini. (Ambarwati dkk, 2015; Dayani, 2017; Susiyanti \& Effendi, 2019), bahwa semakin besar firm size maka semakin tinggi ROA, hasil berbeda, (Meidiyustiani, 2016; Maria et al., 2019), firm size yang kecil menyebabkan pengurangan ROA.

\section{B. KAJIAN LITERATUR}

\section{Manajemen Keuangan}

Manajemen keuangan adalah keseluruhan kegiatan yang dilakukan dengan cara untuk memperoleh, menggunakan dana, dan mengelola asset secara optimal sesuai dengan tujuan keseluruhan perusahaan. (Harjito dan Martono, 2010:4).

\section{Laporan Keuangan}

Laporan keuangan adalah status keuangan perusahaan dalam periode berjalan dan periode tertentu. Suatu informasi yang menunjukkan performa perusahaan, di mana laporan akan menjadi informasi yang menunjukkan kinerja perusahaan. Laporan keuangan adalah output dari suatu proses akuntansi yang menjadi tujuan informasi bagi pengguna ketika membuat keputusan (Fahmi, 2012:22).

\section{Pasar modal}

Secara umum, pasar modal dapat diartikan sebagai tempat di mana pembeli dan penjual bertemu dalam melakukan transaksi untuk mendapatkan dana. Penjual di pasar modal adalah perusahaan yang membutuhkan dana (emiten), sehingga perusahaan menjual sekuritas jangka panjang (terkait dengan investasi) di pasar modal. (Prayudi dkk., 2019).

\section{Rasio Aktivitas}

Kemampuan perusahaan untuk memanfaatkan sumber daya secara maksimal dapat dilakukan dengan cara membandingkan penjualan dengan totasl asset (Sartono, 2014:118). TATO, sebagai refleksi dari kapasitas, bertujuan untuk membandingkan tingkat perputaran aset dengan menghitung total pendapatan per rupiah dalam aset. Rumus perhitungan total aset (Kasmir, 2017:185) adalah : 


$$
\text { total assets turn over }=\frac{\text { penjualan }(\text { sales })}{\text { total aktiva }(\text { total assets })}
$$

\section{Ukuran Perusahaan (Firm size)}

Tingkat perusahaan dapat dinyatakan dengan melalui ekuitas, penjualan, atau aset yang berfungsi memberikan informasi terkait dengan total aset perusahaan (Riyanto, 2011:343). Firm Size adalah skala besar maupun kecilnya perusahaan yang ditunjukkan melalui total aktiva, penjualan, dan kapitalisasi pasar. Formulasi dari firm size (Munawir, 2010:30) adalah sebagai berikut:

$$
\text { Size }=\text { Ln Total Asset }
$$

\section{Rentabilitas}

Rasio Rentabilitas biasanya dinyatakan sebagai profitabilitas yang digunakan untuk menentukan efisiensi bisnis dan perolehan laba perusahaan (Kasmir, 2017:234). Pendapat para ahli lainnya menunjukkan bahwa Rentabilitas suatu perusahaan menggambarkan skala antara laba dengan aset atau modal yang menciptakan laba tersebut. (Riyanto, 2011:159). Pakar lain mengeluarkan pernyataan serupa (Munawir, 2010:33) bahwa Rentabilitas adalah kemampuan perusahaan dalam menciptakan laba dalam suatu periode tertentu yang dihitung melalui ROA (Tandelilin, 2010:372) yaitu :

$$
\mathrm{ROA}=\frac{\text { net income }}{\text { total assets }}
$$

\section{METODOLOGI PENELITIAN}

Penelitian ini merupakan penelitian deskriptif kuantitatif dengan regresi linear berganda desain penelitian time series. Data kuantitatif digunakan karena data tersebut bersifat numerik sehingga dapat dianalisis dengan alat statistik (Sugiyono, 2017:224). Data sekunder digunakan melalui dokumentasi laporan keuangan perusahaan PT. Telekomunikasi Indonesia (Persero), Tbk melalui website www.telkom.co.id dan www.idnfinancial.com serta dari berbagai referensi pendukung. Populasi penelitian adalah Laporan keuangan triwulan Tahun 2009 - 2018. Multiple linear regression melalui pemanfaatan SPSS Ver. 25 digunakan sebagai peralatan penelitian.

\section{HASIL PENELITIAN DAN PEMBAHASAN}

\section{Uji Asumsi Klasik}

a. Uji Normalitas

Tabel 2. Hasil Uji Normalitas (Kolmogorov-Smirnov Test)

\begin{tabular}{lrr}
\hline N & & 40 \\
\hline Normal Parameters & & $4, b$ \\
& Mean & .0000000 \\
\cline { 2 - 3 } Most Extreme Differences & Std. Deviation & .16985988 \\
\hline Absolute & .065 \\
\hline Test Statistic & Positive & .047 \\
\hline Asymp. Sig. (2-tailed) & Negative & -.065 \\
\hline
\end{tabular}
a. Test distribution is Normal.
b. Calculated from data. 
Data yang diuji terdistribusi secara normal, dibuktikan melalui nilai test statistic $=0,065>$ 0,05 dan nilai Kolmogorov-Smirnov Test $=0.200>0.05$.

b. Uji Autokorelasi

Tabel 3. Hasil Uji Autokorelasi

\begin{tabular}{|c|c|c|c|c|}
\hline Model & $\mathrm{R}$ & R Square & Adjusted R Square & Durbin-Watson \\
\hline 1 & $.948^{\mathrm{a}}$ & .900 & .894 & 1.109 \\
\hline
\end{tabular}

a. Predictors: (Constant), Ukuran Perusahaan, Rasio Aktivitas

b. Dependent Variable: Rentabilitas

Hasil pada tabel 3 menunjukkan tidak terjadi auto korelasi positif dibuktikan dengan nilai DW 1.109 lebih dari nol dan kurang dari batas bawah atau lower bound sebesar $1.3908(0<D W<D L)$ atau $0<1.109<1.3908$.

c. Uji Multikoleniaritas

Tabel 4. Hasil Uji Multikoleniaritas

\begin{tabular}{llrr}
\hline \multirow{2}{*}{ Model } & & \multicolumn{2}{c}{ Collinearity Statistics } \\
\cline { 3 - 4 } & & Tolerance & VIF \\
\hline \multirow{2}{*}{ (Constant) } & & 1.001 \\
& Rasio Aktivitas & .999 & 1.001 \\
\hline
\end{tabular}

a. Dependent Variable: Rentabilitas

Hasil pengujian nilai tolerance sebesar $0.999<1$ dan value influence factor $(\mathrm{VIP})=$ $1.001<10$, sehingga dengan demikian dapat dinyatakan bahwa tidak terjadi multikoleniaritas.

d. Uji Heterokeastisitas

\section{Tabel 5. Hasil Uji Glejser}

\begin{tabular}{|c|c|c|c|c|c|c|}
\hline \multirow{2}{*}{\multicolumn{2}{|c|}{ Model }} & \multicolumn{2}{|c|}{ Unstandardized Coefficients } & \multirow{2}{*}{$\begin{array}{c}\text { Standardized } \\
\text { Coefficients } \\
\text { Beta }\end{array}$} & \multirow[b]{2}{*}{$\mathrm{t}$} & \multirow[b]{2}{*}{ Sig. } \\
\hline & & $\mathrm{B}$ & Std. Error & & & \\
\hline \multirow[t]{3}{*}{1} & (Constant) & 2.176 & 1.769 & & 1.230 & .226 \\
\hline & Rasio Aktivitas & -.001 & .001 & -.117 & -.726 & .472 \\
\hline & Ukuran Perusahaan & -.001 & .001 & -.183 & -1.138 & .263 \\
\hline
\end{tabular}

a. Dependent Variable: Heterokedastisitas

Nilai $p$-value pada rasio aktivitas $=0.472>0,05$ dan ukuran perusahaaan $=0.263>$ 0,05 , sehingga berdasarkan uji Glejser Maka dapat disimpulkan bahwa data yang digunakan adalah homogen (tidak terjadi heterokedastisitas). 
e. Uji Linearitas

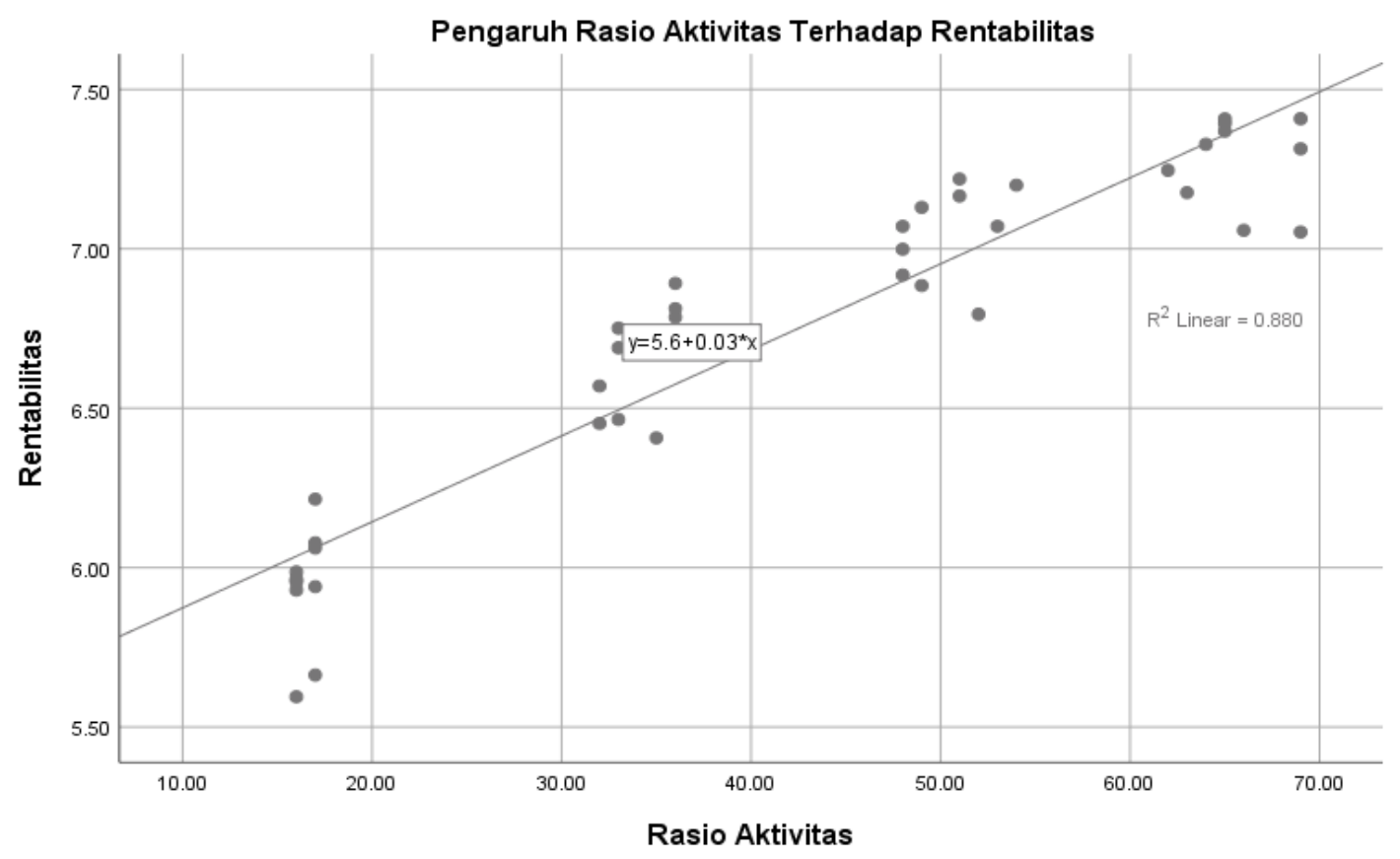

Gambar 1. Linearitas kontribusi rasio aktivitas pada Rentabilitas

Grafik pada gambar 1 menunjukkan bahwa adanya hubungan linear antara rasio aktivitas dengan rentabilitas, kontribusi nilai lineritas $=0.880$.

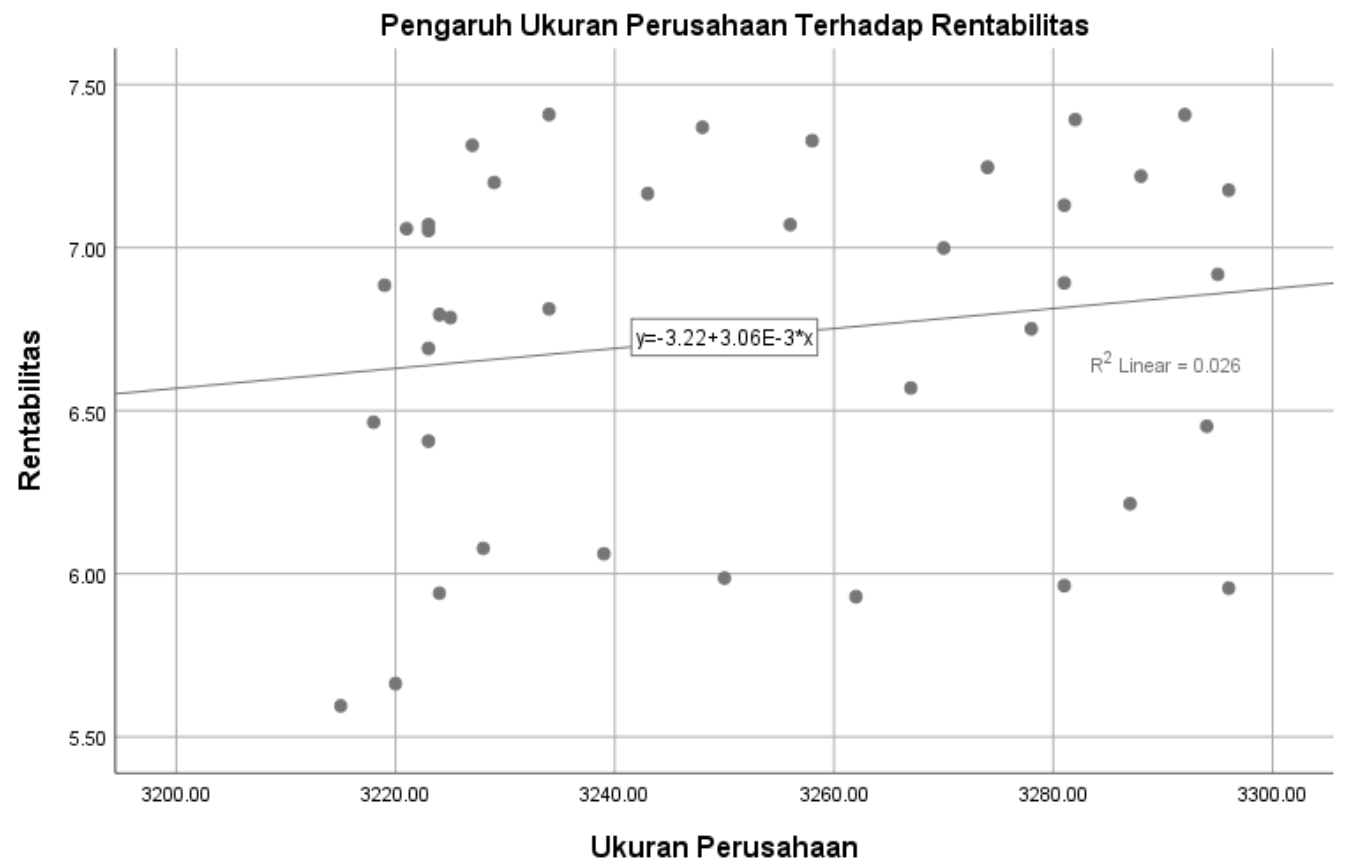

Gambar 2. Linearitas kontribusi ukuran perusahaan pada rentabilitas

Grafik pada Gambar 2 menunjukkan bahwa adanya hubungan linear antara ukuran perusahaan dengan rentabilitas, kontribusi nilai lineritas $=0.026$. 
2. Analisis Statistik Deskriptif

Tabel 6. Statistik Deskriptif

\begin{tabular}{llr|rr}
\multicolumn{7}{c}{ Statistics } & & \\
& \multicolumn{1}{c}{ Aktivitas } & Ukuran_Per & Rentabilitas \\
\hline $\mathrm{N}$ & Valid & 40 & 40 & 40 \\
\cline { 2 - 5 } & Missing & 0 & 0 & 0 \\
\hline Mean & 3.6082 & 8.0870 & 6.7276 \\
\hline Median & 3.7274 & 8.0861 & 6.8484 \\
\hline Std. Deviation & .52830 & .00863 & .53602 \\
\hline Range & 1.46 & .02 & 1.81 \\
\hline Minimum & 2.77 & 8.08 & 5.59 \\
\hline Maximum & 4.23 & 8.10 & 7.41 \\
\hline
\end{tabular}

Dapat dilihat dari Tabel 6 bahwa persentase rata-rata dari variabel Rentabilitas dengan jumlah data $(\mathrm{N}) 40$ adalah 6,7276, dengan nilai minimum sebesar 5,59 dan nilai maksimum adalah 7,41 dengan standar deviasi adalah 0,53602.

Variabel rasio aktivitas dengan jumlah data $(\mathrm{N})$ sebanyak 40 mempunyai presentase rata - rata sebesar 3.6082 dengan nilai minimal sebesar 2.77 dan maksimal 4.23. sedangkan standar deviasinya sebesar 0.52830 .

Variabel ukuran perusahaan dengan jumlah data $(\mathrm{N})$ sebanyak 40 mempunyai presentase rata - rata sebesar 8.0870 dengan nilai minimal sebesar 8.08 dan maksimal 8.10. sedangkan standar deviasinya sebesar 0.00863

3. Uji Regresi Linear Berganda

Penentuan terdapat ataupun tidaknya pengaruh yang posiif signifikan ataupun sebaliknya dapat dilihat pada nilai t-hitung dan $\mathrm{p}$-value, untuk itu hasilnya dapat ditunjukkan sebagai berikut:

Tabel 7. Uji multiple regression

\begin{tabular}{|c|c|c|c|c|c|c|}
\hline \multirow{2}{*}{\multicolumn{2}{|c|}{ Model }} & \multicolumn{2}{|c|}{ Unstandardized Coefficients } & \multirow{2}{*}{$\begin{array}{c}\text { Standardized } \\
\text { Coefficients } \\
\text { Beta } \\
\end{array}$} & \multirow[t]{2}{*}{$\mathrm{t}$} & \multirow[t]{2}{*}{ Sig. } \\
\hline & & $\mathrm{B}$ & Std. Error & & & \\
\hline \multirow[t]{3}{*}{1} & (Constant) & -2.964 & 3.231 & & -.917 & .365 \\
\hline & Rasio Aktivitas & .027 & .001 & .935 & 17.944 & .000 \\
\hline & Ukuran Perusahaan & .003 & .001 & .138 & 2.652 & .012 \\
\hline
\end{tabular}

a. Dependent Variable: Rentabilitas

Berikut hasil dari pengujian yang telah dilakukan :

$Y=-2.964+0.021 X_{1}+0.03 X_{2}+3.231$

Berdasarkan hasil analisis tersebut, maka dapat ditunjukkan bahwa:

1. Angka konstanta sebesar -2.964 menyatakan jika rasio aktivitas $\left(X_{1}\right)$ dan ukuran perusahaaan $\left(\mathrm{X}_{2}\right)$ nilainya 0 , maka harga rentabilitas $(\mathrm{Y})$ nilainya sebesar -2.964 
2. Koefisien rasio aktivitas sebesar 0.027 menyatakan bahwa setiap penambahan $1 \%$ rasio aktivitas, maka akan meningkatkan rentabilitas sebesar 0.027 pada saat variabel lainnya tidak berubah (konstan).

3. Koefisien ukuran perusahaan sebesar 0.003 menyatakan bahwa setiap penambahan $1 \%$ ukuran perusahaan, maka akan meningkatkan rentabilitas sebesar 0.003 pada saat variabel lainnya tidak berubah (konstan).

Kontribusi variabel bebas pada variabel terikat berdasarkan koefisien Determinasi $\left(R^{2}\right)$, adalah sebagai berikut:

Tabel 8. Koefisien Determinasi $\left(\mathbf{R}^{2}\right)$

\begin{tabular}{|c|c|c|c|c|}
\hline Model & $\mathrm{R}$ & R Square & Adjusted R Square & Std. Error of the Estimate \\
\hline 1 & $.948^{a}$ & .900 & .894 & .17439 \\
\hline
\end{tabular}

a. Predictors: (Constant), Ukuran Perusahaan, Rasio Aktivitas

Kedua variable bebas memberikan sumbangan dalam penciptaan rentabilitas perusahaan sebesar 0.894 atau $89.4 \%$, sedangkan untuk kontribusi dari masing masing variable independen dapat ditunjukkan sebagai berikut:

Tabel 9. Kontribusi Variabel Independen Terhadap Variabel Dependen (Rentabilitas)

\begin{tabular}{|l|c|c|c|c|c|}
\hline \multicolumn{1}{|c|}{ Variabel } & $\begin{array}{c}\text { Pearson } \\
\text { Correlation }\end{array}$ & $\rightarrow$ & $\begin{array}{c}\text { Standardized } \\
\text { Coefficients }\end{array}$ & \multicolumn{2}{|c|}{ Kontribusi } \\
\hline Rasio Aktivitas & 0,938 & $\mathrm{X}$ & 0,935 & $\rightarrow$ & 0,877 \\
\hline $\begin{array}{l}\text { Ukuran } \\
\text { Perusahaan }\end{array}$ & 0,160 & $\mathrm{X}$ & 0,138 & $\rightarrow$ & 0,022 \\
\hline
\end{tabular}

Kontribusi pengaruh rasio aktivitas terhadap rentabilitas sebesar $87,70 \%$ sedangkan pengaruh ukuran perusahaan terhadap rentabilitas sebesar 2,20\% sehingga jika dibulatkan maka diperoleh besaran kontribusi (koefisien determinasi) sebesar 0.899579 atau 0,900 $=90.00 \%$ (R Square). Berdasarkan hasil tersebut maka dapat dijelaskan bahwa kontribusi dominan variabel yang mempengaruhi rentabilitas adalah rasio aktivitas dengan total kontribusi sebesar $87,70 \%$

4. Uji-t

Tabel 10. Hasil Uji-t

\begin{tabular}{|c|c|c|c|c|c|c|}
\hline & \multirow[t]{2}{*}{ Model } & \multicolumn{2}{|c|}{ Unstandardized Coefficients } & \multirow{2}{*}{$\begin{array}{c}\text { Standardized } \\
\text { Coefficients } \\
\text { Beta } \\
\end{array}$} & \multirow[t]{2}{*}{$\mathrm{t}$} & \multirow[t]{2}{*}{ Sig. } \\
\hline & & $\mathrm{B}$ & Std. Error & & & \\
\hline \multirow[t]{3}{*}{1} & (Constant) & -2.964 & 3.231 & & -.917 & .365 \\
\hline & Rasio Aktivitas & .027 & .001 & .935 & 17.944 & .000 \\
\hline & Ukuran Perusahaan & .003 & .001 & .138 & 2.652 & .012 \\
\hline
\end{tabular}

a. Dependent Variable: Rentabilitas 


\section{a. Rasio Aktivitas pada Rentabilitas}

Berdasarkan hasil pengujian diperoleh nilai $t_{-}{ }_{\text {hitung }} 17.944>t_{\text {abel }} 2.026$ dengan $p$-value sebesar $0.000<0.05$, nilai koefisien regresi variabel Rasio Aktivitas adalah 0.027 (positif).Hasil tersebut menjelaskan bahwa rasio aktivitas terbukti dapat memberikan kontribusi positif dan signifikan pada rentabilitas.

\section{b. Ukuran Perusahaan pada Rentabilitas}

Berdasarkan hasil pengujian nilai $t_{-h i t u n g} 2.652>t_{-a b e l} 2.026$ dengan $p$-value sebesar $0.012<0.05$. Nilai koefisien regresi variabel Ukuran Perusahaan adalah 0.0003 (positif). Perolehan tersebut menjelaskan bahwa ukuran perusahaan terbukti dapat memberikan kontribusi positif dan signifikan pada rentabilitas.

\section{Uji Kelayakan Model (Uji Fisher Test)}

\section{Tabel 11. Uji Kelayakan Model (Uji Fisher Test)}

\begin{tabular}{ll|r|r|r|r|r} 
Model & & Sum of Squares & df & Mean Square & F & Sig. \\
\hline 1 & Regression & 10.080 & 2 & 5.040 & 165.725 & $.000^{\mathrm{b}}$ \\
\hline & Residual & 1.125 & 37 & .030 & & \\
\hline & 11.205 & 39 & & & \\
\hline
\end{tabular}

a. Dependent Variable: Rentabilitas

b. Predictors: (Constant), Ukuran Perusahaan, Rasio Aktivitas

Berdasarkan hasil pengolaan menunjukkan hasil pengujian model diperoleh nilai $\mathrm{F}_{\text {hitung }}$ sebesar 165.725 dan nilai $F_{- \text {tabel }}$ dengan derajat kekeliruan $5 \%$ dan dan derajat bebas $(2 ; 37)$ sehingga diperoleh $\mathrm{F}_{\text {tabel }}$ sebesar 3.2519. Oleh karena itu, hasil tersebut menunjukkan bahwa nilai $\mathrm{F}_{\text {-hitung }}>$ dari $\mathrm{F}_{\text {-tabel }}$ yang menunjukkan bahwa model tersebut layak (memenuhi kelayakan model).

\section{E. KESIMPULAN}

Hasil panalisis data statistik terhadap kontribusi rasio aktivitas dan ukuran perusahaan pada rentabilitas PT. Telekomunikasi Indonesia (Persero), Tbk, dapat disimpulkan bahwa:

1. Semakin tinggi kontribusi Rasio Aktivitas (TATO), maka semakin meningkat rentabilitas perusahaan

2. Tingginya kontribusi Ukuran Perusahaan (LnTA) berdampak pada peningkatan rentabilitas perusahaan

Hasil studi ini memberikan rekomendasi , antara lain:

1. Peningkatan kepercayaan investor dapat dilakukan dengan meningkatkan rentabilitas perusahaan melalui rasio aktivitas dan ukuran perusahaan sebab semakin tinggi rentabilitas perusahaan maka hal tersebut dapat menarik minat para investor.

2. Kepada peneliti lanjutan diharapkan dapat mengembangkan model penelitian ini dengan memasukkan variabel bebas lainnya yang dapat mempengaruhi rentabilitas perusahaan. 


\section{DAFTAR PUSTAKA}

Ambarwati, N. S., Yuniarta, G. A., dan Sinarwati, N. K. (2015). Pengaruh Working Capital, Likuiditas, Aktivitas dan Ukuran Perusahaan Terhadap Profitabilitas Pada Perusahaan Manufaktur yang Terdaftar di Bursa Efek Indonesia. E-Journal S1 Ak Universitas Pendidikan Ganesha, 3(1), 11.

Besley, S., dan Brigham, E. F. (2008). Essential of Managerial Finance. USA: South Western.

Dayani, putri marta. (2017). Pengaruh Leverage, Activity Ratio Dan Firm Size Terhadap Rentabilitas Ekonomi Perusahaan Agriculture Di Bei Periode 2011-2015. 4(1), 9-15.

Destika, D. M. (2016). Analisis Pengaruh Rasio Aktivitas Terhadap Rentabilitas Ekonomi (pada Perusahaan Makanan dan Minuman yang Go Public di BEI Periode 2011-2014).

Fahmi, I. (2012). Analisa Kinerja Keuangan. Bandung: Alfabeta.

Handayani, H., dan Hadi, S. (2019). Pengaruh Activity Ratio dan Profitability Pada Perusahaan Farmasi Yang Go Public Di BEl Periode 2013-2017. Jurnal Illmiah Akuntansi, 3(2), 146-157.

Harjito, A., dan Martono. (2010). Manajemen Keuangan. Yogyakarta: Ekonisia.

Hasibuan, P. M. H. (2019). Pengaruh Firm Size, Rasio Aktivitas, Leverage dan Likuiditas Terhadap Kinerja Keuangan pada Perusahaan Properti dan Perumahan yang Go Public di BEI Periode 2013-2017.

Kasmir. (2017). Analisis Laporan Keuangan. Jakarta: PT. Rajagrafindo persada.

Maria, M., Wiagustini, L. ., dan Sedana, I. B. P. (2019). Pengaruh Firm Size, Leverage Dan Liquiditas Terhadap Profitabilitas Di Perusahaan Esperanca Timor-Oan (Eto) Dili TimorLeste. Ekonomi Dan Bisnis, 1, 23-40.

Meidiyustiani, R. (2016). Pengaruh Working Capital, Firm size, Pertumbuhan Penjualan, Dan Liquidity Terhadap Profitability Pada Perusahaan Manufaktur. Jurnal Akuntansi Dan Keuangan, 5(2), 131-143. https://doi.org/10.25170/jm.v15i1.95

Munawir, S. (2010). Analisis Laporan Keuangan (Edisi ke-4). Yogyakarta: Liberty.

Pratama, I. G. B. A., dan Wiksuana, I. G. B. (2016). Pengaruh Leverage Dan Firm Size Terhadap Working Capital Dengan Profitabilitas menjadi Variabel Mediasi. E-Jurnal Manajemen Universitas Udayana, 5(2), 1338-1367. https://doi.org/10.24843/ejmunud.2019.v08.i05.p16

Prayudi, M. A., Sari Dewi, G. A. K. R., Vijaya, D. P., dan Ekawati, L. P. (2019). Teori Peran Dan Konsep Expectation-Gap Fungsi Pengawasan Dalam Pengelolaan Keuangan Desa. EKUITAS (Jurnal Ekonomi Dan Keuangan), 2(4), 449. https://doi.org/10.24034/j25485024.y2018.v2.i4.3931

Riyanto, B. (2011). Dasar - Dasar Pembelanjaan Perusahaan (Edisi Ke-4). Yogyakarta.

Sartono, A. (2014). Teori Manajemen Keuangan dan Aplikasi (Edisi Ke-4). Jakarta: Kencana Prenamedia Group.

Sunardi, N. (2019, January). Relevansi Struktur Kepemilikan Tentang Profitabilitas Dan Nilai Perusahaan (Studi pada Industri Manufaktur yang Terdaftar di Bursa Efek Indonesia 
Periode 2010-2017). In Proceedings (Vol. 1, No. 1).

Sunardi, N. (2019). Profitabilitas, Likuiditas, Dan Multiplier Equity Pengaruhnya Terhadap Harga Serta Return Saham Pada Industri Manufaktur Tahun 2012-2017. INOVASI, 6(1), 58-73.

Sunardi, N. (2017). Pengaruh Profitabilitas, Firm Size, Risiko Bisnis, Asset Growth, Leverage, Kebijakan Dividen Terhadap Institutional Ownership (Perusahaan Property \& Real Estate yang terdaftar di Bursa Efek Indonesia Tahun 2011-2014). INOVASI, 2(2)

Setiawan, E. (2015). Pengaruh Cr, Ito, Tato, Penjualan, Dan Ukuran Perusahaan Terhadap Roa Pada Perusahaan Makanaan Dan Minuman Yang Terdaftar Di BEI Periode 20102013. 151, 10-17. https://doi.org/10.1145/3132847.3132886

Sugiyono. (2017). Metode Penelitian Kuantitatif, Kualitatif dan R\&D. Bandung: Alfabeta, CV.

Sukmayanti, N. W. P., dan Triaryati Nyoman. (2019). Pengaruh Capital Structure, Likuiditas Dan Ukuran Perusahaan Terhadap Profitabilitas Pada Perusahaan Properti Dan Perumahan. 8(1), 7132-7162.

Susanto, A. (2013). Teori Belajar dan Pembelajaran di Sekolah Dasar. Jakarta: Kencana Prenamedia Group.

Susiyanti, S., dan Effendi, B. (2019). Struktur Modal, Firm Size, Likuiditas dan Profitability Perusahaan Manufaktur yang Listing di BEl. Owner, 3(2), 66. https://doi.org/10.33395/owner.v3i2.137

Tandelilin, E. (2010). Portofolio dan Teori Investasi dan Aplikasi (Edisi Ke-1). Yogyakarta: Kanisius.

Lutfi, A. M., \& Sunardi, N. (2019). Pengaruh Current Ratio (Cr), Return On Equity (Roe), Dan Sales Growth Terhadap Harga Saham Yang Berdampak Pada Kinerja Keuangan Perusahaan (Pada Perusahaan Manufaktur Sektor Makanan Dan Minuman Yang Terdaftar Di Bursa Efek Indonesia). Jurnal SEKURITAS (Saham, Ekonomi, Keuangan dan Investasi), 2(3), 83-100. 